\title{
OPEN Assessment of the pollution levels of potential toxic elements in urban vegetable gardens in southwest China
}

\author{
Jianing Gao ${ }^{1,2}$, Dan Zhang ${ }^{1 \bowtie}$, Ram Proshad ${ }^{1,2}$, Ernest Uwiringiyimana ${ }^{1,2}$ \& Zifa Wang ${ }^{3}$
}

Vegetable gardens are increasingly common in urban areas and can provide numerous societal benefits; however, contamination with potential toxic elements (PTEs) due to urbanization and industrialization is cause for concern. The present study aimed to assess the source of contamination and pollution levels in urban garden soils, as well as the health risks for adults and children consuming vegetables grown in such environments. Various types of vegetable samples and their corresponding soils from 26 community gardens were collected throughout Chengdu City in southwestern China. The results showed that leafy vegetables, particularly lettuce leaves and Chinese cabbage, had relatively higher levels of $\mathrm{Cd}(0.04 \mathrm{mg} / \mathrm{kg} \mathrm{FW})$ and $\mathrm{Pb}(0.05 \mathrm{mg} / \mathrm{kg} \mathrm{FW})$, while higher levels of $\mathrm{As}(0.07 \mathrm{mg} / \mathrm{kg} \mathrm{FW})$, $\mathrm{Cr}(0.07 \mathrm{mg} / \mathrm{kg} \mathrm{FW})$, and $\mathrm{Hg}(0.003 \mathrm{mg} / \mathrm{kg} \mathrm{FW})$ were found in amaranths, tomatoes, and Houttuynia cordatas, respectively. The pollution indices revealed that the vegetable purplish soils were relatively more polluted by $\mathrm{Cd}$ and $\mathrm{As}$, and the concentrations of these metals in vegetables were correlated with their concentrations in the soils. Principal component analysis grouped the PTEs in two dimensions that cumulatively explained $62.3 \%$ of their variation, and hierarchical clustering identified two distinct clusters indicating that $\mathrm{Cr}$ originated from a unique source. The health risk assessment revealed that exposure to As and Cd induced the greatest non-carcinogenic risk, whereas $\mathrm{Cr}$ was most likely to cause cancer risks. Furthermore, contaminated vegetable consumption was riskier for children than adults. The critical factors contributing to PTE contamination in vegetable gardens were determined to be vegetable species, total soil element content, soil $\mathrm{pH}$, and soil organic matter content. Overall, $\mathrm{Cr}$ and As pollution present the greatest concern, and community health care services must enact more effective regulatory and preventative measures for urban gardens in terms of PTEs.

Soil is considered a vital component contributing to human survival on the earth because of its role as a nutrient benefactor for plant growth; however, soil is also anticipated to be a principal recipient of potential toxic elements (PTEs) $)^{1-3}$. The presence of PTEs in soil has emerged as a significant problem in many parts of the world, including China, as a result of abrupt urbanization and industrialization in combination with rapid population growth over the last few years ${ }^{4,5}$. Pollution from PTEs affects the soil composition, texture, and function of urban garden areas, as well as introverted plant root development, thereby reducing crop production ${ }^{6,7}$. The abundance, persistence, and environmental toxicity of PTEs can directly or indirectly induce detrimental consequences on human health by propagating through the food chain ${ }^{6,8,9}$. Therefore, the scientific research community has recently dedicated more attention to investigating potential means of particulate deposition and monitoring PTE levels in the environment ${ }^{6,10,11}$.

In China, pollution with toxic elements has become an increasingly serious issue, leading to increased public concern about the possible accumulation of heavy metals in agricultural soils, which ultimately poses a major threat to human health through the food chain ${ }^{3,12}$. Vegetable consumption is a key part of Chinese people's diets, and it therefore represents a likely pathway by which toxic element contamination can climb the food chain and affect human health ${ }^{5,8,13}$.

\footnotetext{
${ }^{1}$ Key Laboratory of Mountain Surface Processes and Ecological Regulation, Institute of Mountain Hazards and Environment, Chinese Academy of Sciences, \#9, Block 4, Renminnanlu Road, Chengdu 610041, Sichuan, People's Republic of China. ${ }^{2}$ University of Chinese Academy of Sciences, Beijing, People's Republic of China. ${ }^{3}$ Institute of Atmospheric Physics, Chinese Academy of Sciences, Beijing, People's Republic of China. ${ }^{\boxplus}$ email: daniezhang@ imde.ac.cn
} 


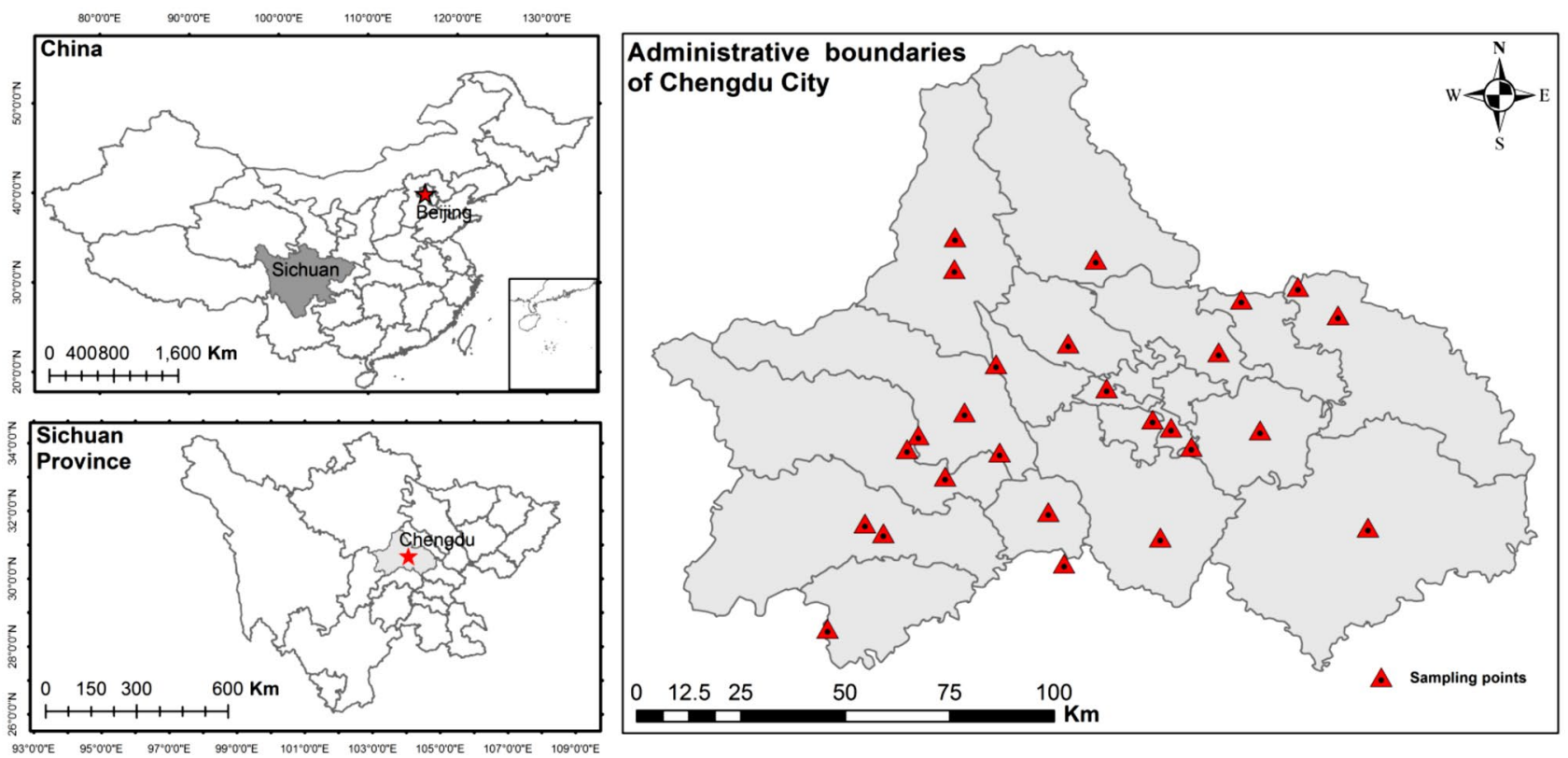

Figure 1. Map of the study area showing the sampling sites in Chengdu City, Southwest China. The maps were created using ArcMap version 10.4 software (https://desktop.arcgis.com/). The administrative boundaries data were accessed via http://211.159.153.75/.

Urban vegetables garden is one of major form of urban agriculture in the world as well as China that act as an important feature of urban food security and sustainable urban food systems ${ }^{14,15}$. Urban gardens are characterized by a wide range of agricultural and industrial activities and are found in the urban areas ${ }^{16}$. Because urban regions are often subjected to several emission sources of vegetable garden soils contamination by heavy metals is more severe and complicated. Urban garden soils and vegetables contamination can be burning issues in the subject of ecological risks and human health hazards. Industrial operations, irrigation with polluted water and atmospheric deposition in the urban regions resulting metal pollution in soil and vegetables ${ }^{17-19}$. Soil acts as reservoir of toxic metals accumulation that transfer to vegetables and enter into human food chain that cause non-carcinogenic and carcinogenic health hazards due to consumption of contaminated vegetables ${ }^{17,20}$.

Southwest China is the most prominent commercial and industrial region in the country, so urban soil in this region is significantly influenced by the emission of pollutants from various surrounding industries and heavy traffic. Numerous studies have investigated the PTE pollution in agricultural soils in southeastern Chinese provinces, such as Zhejiang ${ }^{21,22}$, Jiangsu ${ }^{23,24}$, Guangdong ${ }^{25}$, and Shandong ${ }^{24}$. However, to our knowledge, no comprehensive assessments have focused on PTE pollution in urban garden soils and vegetables in southwestern China. Moreover, there is generally insufficient information regarding PTE pollution in this region. Therefore, present study was conducted to measure the PTE levels in urban garden soils and vegetables and to determine their possible sources of metals with possible health risks for adults and children exposed to PTEs in urban vegetable gardens. The PTE concentrations in urban soil and vegetables were compared with the results of several studies conducted around the world to assess the relative pollution levels of southwest China's urban vegetable gardens in a global context.

\section{Materials and methods}

Study area. This study was conducted in Chengdu City, Sichuan Province $\left(102^{\circ} 54^{\prime} \mathrm{E}-104^{\circ} 53^{\prime} \mathrm{E}\right.$, $30^{\circ} 05^{\prime} \mathrm{N}-31^{\circ} 26^{\prime} \mathrm{N}$ ), which is one of the most cardinal megacities in China and in the world, with a population of more than 16 million, where the urban population density is approximately 6500 people $/ \mathrm{km}^{2}$. Topographically, Chengdu City is located in the western part of the Sichuan Basin, surrounded by the Longquan Mountains in the east and the Qionglai Mountains in the west ${ }^{26}$. It has a subtropical monsoon humid climate with a mean annual temperature of $15.5{ }^{\circ} \mathrm{C}$ and a mean annual rainfall of $1000 \mathrm{~mm}$. The main soil types present in this region are lateritic red soil, fluvo soil, purplish soil, and paddy soil.

Sampling. A total of 113 topsoil (from 0 to $20 \mathrm{~cm}$ deep) samples, including 63 purplish soils and 50 yellow soils, and their corresponding vegetable samples ( $0.5 \mathrm{~kg}$ edible part of each) were collected from 26 community gardens in the sampling area, as shown in Fig. 1. Up to four samples were collected from different locations in each garden, and analyzed individually, depending on the field survey characteristics (i.e., soil type, vegetable species, and regional specifications). The vegetables analyzed included 51 leafy vegetables (i.e., 15 amaranths, 21 Chinese cabbage, 15 lettuce leaves), 24 rootstock vegetables (i.e., 12 carrots and 12 Houttuynia cordatas), 26 legume vegetables (i.e., 12 pea pods and 14 cowpeas), and 12 solanaceous vegetables (12 tomatoes). All soil and vegetable specimens were blended from three random subsamples. 
Pre-treatment and analysis of soil and vegetable samples. All soil samples were homogenized, air-dried, pulverized, and passed through a $2-\mathrm{mm}$ sieve. The soil $\mathrm{pH}$ was measured using a $\mathrm{pH}$ meter with a soil:water ratio of $1: 2.5^{27}$. The soil organic matter (SOM) was determined via wet oxidation at $180{ }^{\circ} \mathrm{C}$ with a mixture of potassium dichromate and sulfuric acid ${ }^{28}$. The total $\mathrm{Cd}, \mathrm{Pb}, \mathrm{Cr}, \mathrm{As}$, and $\mathrm{Hg}$ were dissolved in pure hydrochloric acid and nitric acid in the microwave.

Vegetables were carefully rinsed with distilled water to remove dust and impurities attached to the leaf and/ or root surface. All edible parts were extracted with nitric acid, hydrogen peroxide, and hydrofluoric acid to determine the concentrations of PTEs. The concentrations of $\mathrm{Cd}, \mathrm{Pb}, \mathrm{Cr}$, and As in soils and plants were measured in triplicate using inductively coupled plasma mass spectrometry (ICP-MS; Agilent 7700x, USA). The concentration of $\mathrm{Hg}$ was measured with an atomic fluorescence spectrometer (AFS; PF6-3, China). Quality assurance and quality control were performed by duplicate samples, blanks and standard substances. The relative standard deviation (RSD) of the duplicates was less than $6 \%$, and the recovery rates of the standard substances were $104 \%$ and 95\%, respectively. All PTE concentrations were determined on a dry weight (DW) basis, and are expressed herein in units of $\mathrm{mg} / \mathrm{kg} \mathrm{DW}$.

Ecological risk assessments. Geo-accumulation index. The geo-accumulation index $\left(I_{\text {geo }}\right)$ was determined to assess the contamination levels of PTEs in the study area ${ }^{29}$. The $I_{\text {geo }}$ values were calculated using Eq. (1),

$$
I_{g e o}=\log _{2}\left(\frac{C_{k}}{1.5 B_{k}}\right)
$$

where $C_{k}(\mathrm{mg} / \mathrm{kg})$ is the measured PTE concentration in the soil and $B_{k}(\mathrm{mg} / \mathrm{kg})$ is the geochemical background value of PTEs in the studied soil. The constant 1.5 was employed to minimize the probable variations in the background values ${ }^{30}$. The $I_{\text {geo }}$ for contamination levels were classified as follows: Class I $\left(I_{\text {geo }} \leq 0\right)$; Class II $\left(0<I_{\text {geo }}\right.$ $\leq 1)$; Class III $\left(1<I_{\text {geo }} \leq 2\right)$; Class IV $\left(2<I_{\text {geo }} \leq 3\right)$; Class V $\left(3<I_{\text {geo }} \leq 4\right)$; Class VI $\left(4<I_{\text {geo }} \leq 5\right)$; Class VII $\left(I_{\text {geo }}>5\right)^{31}$.

Pollution index. The pollution index $(P I)$ is the ratio between the total detected PTE contents in soil and their corresponding background levels ${ }^{32}$. This parameter was calculated using Eq. (2),

$$
P I=\frac{C_{k}}{B_{k}}
$$

The degree of pollution can be classified as follows: low level $(P I<1)$; moderate level $(1 \leq P I<3)$; high level $(P I \geq 3)^{33}$.

Pollution load index. The pollution load index (PLI) is an integrated pollution index, which is determined as the $n^{\text {th }}$ root of the pollution index, as described by Eq. (3),

$$
P L I=\left(P I_{k 1} \times P I_{k 2} \times \cdots \times P I_{k n}\right)^{1 / n}
$$

where $P I_{\mathrm{k} 1}, P I_{\mathrm{k} 2}$, and $P I_{\mathrm{kn}}$ are the $P I$ values of element $k 1, k 2, \ldots k \mathrm{n}$, and $n$ is the number of measured elements. A value of $P L I>1$ indicates that the studied soil was polluted by PTEs ${ }^{33}$.

Bio-accumulation and health risk assessment. Bio-accumulation factor. The bio-accumulation factor (BAF) is an index of the ability of the edible part of a vegetable to accumulate a particular metal ion with respect to its concentration in the soil substrate. This factor can be calculated using Eq. (4),

$$
B A F=\frac{C_{\text {vegs }}}{C_{\text {soil }}}
$$

where $C_{\text {vegs }}(\mathrm{mg} / \mathrm{kg} \mathrm{DW})$ and $C_{\text {soil }}$ represent the PTE concentrations in the edible part of vegetables and in the soil, respectively.

Health risk assessment. We have determined metals concentration in dry weight basis but for daily intake estimation, we need to convert metal concentration in fresh weight basis ${ }^{34}$ using Eq. (5),

$$
F_{w c}=C_{d w}\left[\frac{100-W}{100}\right]
$$

where, $F_{w c}$ is the fresh weight concentration; $C_{d w}$ indicates dry-weight concentration and $\mathrm{W}$ represents percent water content in individual vegetables.

The estimated daily intake (EDI) can be determined using Eq. (6),

$$
E D I_{\text {vegs }}=\frac{C_{\text {vegs }} \times D C R_{\text {vegs }} \times E F \times E D}{B W \times A T}
$$

where $C_{\text {vegs }}$ indicates the metal concentration in vegetables in fresh weight basis (Wang et al., 2020); $D C R_{\text {vegs }}$ represents the daily average consumption rate of vegetables in this area $(76 \mathrm{~g} / \mathrm{day}$ for adults and $59 \mathrm{~g} / \mathrm{day}$ for children $)^{35}$; EF is the exposure frequency (350 days/year) ${ }^{36}$; ED is the exposure duration (76.3 years for adults 


\begin{tabular}{|c|c|c|c|c|c|c|c|c|c|}
\hline \multirow[b]{2}{*}{ Properties } & \multicolumn{4}{|c|}{ Concentrations $(n=113)$} & \multirow[b]{2}{*}{ SD } & \multirow[b]{2}{*}{ CV } & \multirow[b]{2}{*}{ BV } & \multirow[b]{2}{*}{ RV } & \multirow[b]{2}{*}{$\mathbf{p}(\mathrm{K}-\mathrm{S})$} \\
\hline & Min & Max & Mean & Median & & & & & \\
\hline $\mathrm{pH}$ & 4.29 & 8.05 & 6.55 & 6.69 & 0.87 & 0.13 & & & 0.038 \\
\hline $\mathrm{SOM}(\mathrm{g} / \mathrm{kg})$ & 10.25 & 153.88 & 55.63 & 55.69 & 26.99 & 0.49 & & & 0.521 \\
\hline $\mathrm{Cd}(\mathrm{mg} / \mathrm{kg})$ & 0.10 & 0.69 & 0.22 & 0.18 & 0.13 & 0.57 & 0.08 & 0.3 & 0.000 \\
\hline $\mathrm{Pb}(\mathrm{mg} / \mathrm{kg})$ & 11.59 & 82.60 & 35.29 & 31.01 & 14.33 & 0.41 & 30.9 & 90 & 0.004 \\
\hline $\mathrm{Cr}(\mathrm{mg} / \mathrm{kg})$ & 59.21 & 143.14 & 90.91 & 86.30 & 19.55 & 0.21 & 79 & 150 & 0.033 \\
\hline As $(\mathrm{mg} / \mathrm{kg})$ & 8.17 & 61.57 & 29.57 & 27.51 & 13.12 & 0.44 & 10.4 & 40 & 0.015 \\
\hline $\mathrm{Hg}(\mathrm{mg} / \mathrm{kg})$ & 0.01 & 0.10 & 0.06 & 0.06 & 0.02 & 0.34 & 0.061 & 1.8 & 0.914 \\
\hline
\end{tabular}

Table 1. Characteristics of garden vegetable soils in Chengdu City. SD standard deviation, $C V$ coefficient of variation, $B V$ background values (CNEMC, 1990), $R V$ regulation values (CEPA, 2018), $p(K-S) p$ value of Kolmogorov-Smirnov test.

and 6 years for children $)^{35,36}$; BW is the average body weight ( $60 \mathrm{~kg}$ for adults and $25 \mathrm{~kg}$ for children $)^{37}$; AT is the average time for non-carcinogens $(365 \times \mathrm{ED})^{38}$.

The risk assessment evaluated non-carcinogenic and carcinogenic risks associated with PTEs via diet exposure pathways. The non-carcinogenic risk of individual toxic elements, expressed as the hazard quotient $(H Q)$, was calculated using Eq. (7),

$$
H Q=\frac{E D I_{k}}{R F D_{k}}
$$

where $R F D_{\mathrm{k}}$ is the oral reference dose of the PTE. The RFD values for $\mathrm{Cd}, \mathrm{Pb}, \mathrm{Cr}, \mathrm{As}$, and $\mathrm{Hg}$ are $0.0005,0.0035$, $0.003,0.0003$, and $0.0001 \mathrm{mg} / \mathrm{kg} /$ day, respectively ${ }^{38,39}$.

The non-carcinogenic risk of multiple elements, expressed as the hazard index $(H I)$, was determined from Eq. (8),

$$
H I=\sum H Q_{k n}
$$

where a value of $H I>1$ indicates that there is an increasing non-carcinogenic risk, and vice versa for $H I<1$.

The carcinogenic risk (CR) via oral exposure pathways can be evaluated from Eq. (9),

$$
C R=E D I_{k} \times S F_{k}
$$

where $S F_{k}$ is the oral slope factor for different PTEs. The $S F$ values for $\mathrm{Cd}, \mathrm{Pb}, \mathrm{Cr}$, and As are $5 \times 10^{-5}, 8.5 \times 10^{-3}, 41$, and $1.5 \mathrm{mg} / \mathrm{kg} /$ day, respectively ${ }^{36,39}$. The acceptable cancer risk range is between $10^{-6}$ and $10^{-4}$. Values surpassing $10^{-4}$ are considered to pose significant health effects and risks while below $10^{-6}$ are viewed as lower health effect ${ }^{36}$.

The cumulative carcinogenic risk (TCR) can be computed from Eq. (10),

$$
T C R=\sum C R_{k n}
$$

Data analysis. Basic statistical analysis of the raw data was carried out using SPSS 20.0 software. One-way analysis of variance (ANOVA) was performed to determine the significant differences in PTE concentrations in vegetable and soil samples. Comparisons of means were carried out via the Duncan test at a 5\% level of significance. Spearman correlations, principal component analysis (PCA), and cluster analysis (CA) based on squared Euclidean distances were applied to evaluate possible sources of the PTEs in the study area. The maps were created using ArcGIS version 10.4 software.

Ethics approval and consent to participate. All the experimental protocols involving plants adhered to relevant ethical guidelines.

Vegetables collection permission from community gardens was obtained verbally from their owners.

\section{Results}

PTE concentrations in garden soils. The PTE concentrations and physicochemical properties of the studied garden soils are presented in Table 1 . The data were not normally distributed (Kolmogorov-Smirnov test, $p<0.05$ ), except in the case of SOM and Hg. The $\mathrm{pH}$ of the 113 soil samples ranged from 4.29 to 8.05 with an average value of 6.55 , which suggested that the soil in study area was mostly neutral. The SOM content ranged from 10.25 to $153.88 \mathrm{~g} / \mathrm{kg}$, revealing that the SOM of garden vegetable soils in Chengdu City varied greatly. The concentrations of $\mathrm{Cd}, \mathrm{Pb}, \mathrm{Cr}, \mathrm{As}$, and $\mathrm{Hg}$ in the soil were $0.10-0.69,11.59-82.60,59.21-143.14,8.17-61.57$, and $0.01-0.10 \mathrm{mg} / \mathrm{kg}$, with average concentrations of $0.22,35.29,90.91,29.57$, and $0.06 \mathrm{mg} / \mathrm{kg}$, respectively (Table 1). According to the background values of PTEs in the superficial soil of Sichuan Province ${ }^{40}$, most of samples exceeded the background values for all elements. The topsoil samples were significantly enriched by $\mathrm{Cd}$, followed by $\mathrm{As}(96 \%), \mathrm{Cr}(77.9 \%), \mathrm{Hg}(52 \%)$, and $\mathrm{Pb}(51.3 \%)$. There are only a few soil samples wherein the $\mathrm{Pb}, \mathrm{Cr}$, and $\mathrm{Hg}$ concentrations exceeded the regulation values, except in the case of $\mathrm{Cd}(16.8 \%)$ and $\mathrm{As}(19.5 \%)$. 


\begin{tabular}{|l|l|l|l|l|l|l|l|}
\hline & $\mathbf{p H}$ & SOM & Cd & Pb & Cr & As & Hg \\
\hline $\mathrm{pH}$ & 1 & & & & & & \\
\hline $\mathrm{SOM}$ & 0.133 & 1 & & & & & \\
\hline $\mathrm{Cd}$ & 0.005 & 0.034 & 1 & & & & \\
\hline $\mathrm{Pb}$ & -0.103 & $0.231^{\star}$ & $0.416^{* *}$ & 1 & & & \\
\hline $\mathrm{Cr}$ & $-0.260^{* *}$ & 0.183 & $0.293^{* *}$ & $0.259^{* *}$ & 1 & & \\
\hline $\mathrm{As}$ & $-0.271^{* *}$ & $-0.279^{* *}$ & 0.175 & $0.270^{* *}$ & $0.278^{* *}$ & 1 & \\
\hline $\mathrm{Hg}$ & 0.128 & 0.126 & -0.095 & 0.109 & -0.179 & $-0.249^{* *}$ & 1 \\
\hline
\end{tabular}

Table 2. Spearman correlation matrix for soil properties and PTEs in the vegetable soils of Chengdu City $(n=113) .{ }^{\star}$ Significant correlation at 0.05 level. ${ }^{\star *}$ Significant correlation at 0.01 level.

Spearman correlation analysis, PCA, and CA were used to determine the possible sources of soil PTEs in the study area. Table 2 presents the correlation coefficients between soil properties and PTEs in the garden vegetable soils. Significant negative correlations were observed between $\mathrm{pH}$ and $\mathrm{Cr}(r=-0.260, p<0.01), \mathrm{pH}$ and As $(r=-0.271, p<0.05)$, SOM and As $(r=-0.279, p<0.01)$, and $\mathrm{Hg}$ and As $(r=-0.249, p<0.01)$. A significant positive correlation at the level of 0.05 or 0.01 was observed between the elemental pairs $\mathrm{Cd}-\mathrm{Pb}(0.416), \mathrm{Cd}-\mathrm{Cr}$ (0.293), $\mathrm{Pb}-\mathrm{Cr}$ (0.259), Pb-As (0.270), Cr-As (0.278), and Pb-SOM (0.231); the similar ranges of these correlations indicated that the elements possibly originated from the same source ${ }^{41}$.

The results of PCA obtained by applying varimax rotation with Kaiser Normalization for PTE concentrations in garden vegetable soils are shown in Table S1. The eigenvalue of the first extracted factor was much greater than 1 , and the second also exceeded one after the matrix rotation. These results indicated that PCA reduces the initial dimensions of the dataset to two components, which cumulatively explain $62.3 \%$ of the data variation. The first principal component (PC1) explains $36.83 \%$ of the total variance and loads heavily on $\mathrm{Cd}, \mathrm{Pb}$, and $\mathrm{Cr}$, while As was only partially accounted for. The second principal component (PC2), dominated by Hg, accounts for $25.47 \%$ of the total variance. The CA results for PTEs in garden soils are presented as a dendrogram in Fig. S1, which displays two clusters: (1) Cd-Hg-Pb-As; (2) Cr. These CA results suggested at least two different sources of PTEs in the garden vegetable soils. Based on the statistical analysis results, we can consider that $\mathrm{Cd}, \mathrm{Pb}$, and $\mathrm{Hg}$ exclusively (and As partially) had a common source, while $\mathrm{Cr}$ had a distinct source.

Pollution indices. The $I_{\text {geo }}$ and $P I$ values were considered jointly as indices to assess the contamination levels of PTEs in the soil samples ${ }^{41,42}$, and the results based on pollution indices are shown in Fig. 2.

The $I_{\text {geo }}$ values of Cd ranged from -0.24 to 2.53 , and $57.5 \%$ and $24.8 \%$ of sampling sites belonged to Class II and Class III, respectively. For As, $59.3 \%$ and $31.9 \%$ of the samples belonged to Class II and Class III, respectively. These results are consistent with uncontaminated to moderate contamination of $\mathrm{Cd}$ and As in most sampling sites, with a high proportion of moderate contamination conditions. The $I_{\text {geo }}$ values of $\mathrm{Cr}$ and $\mathrm{Hg}$ ranged from -1.0 to 0.27 and -2.89 to 0.12 , respectively, and $11.5 \%$ and $8 \%$ of the respective samples belonged to Class II. These results suggested that most sampling sites were not contaminated with $\mathrm{Cr}$ or $\mathrm{Hg}$, although a few samples were contaminated with these PTEs. Compared with $\mathrm{Cr}$ and $\mathrm{Hg}, \mathrm{Pb}$ exhibited relatively higher $I_{\text {geo }}$ values in Class II, accounting for $27.4 \%$ (Fig. 2a). Accordingly, the PI results revealed that the contamination level of Cd and As for the majority of the sampling sites were at a moderate level. Additionally, the $\mathrm{PI}$ values for $\mathrm{Cr}, \mathrm{Hg}$, and $\mathrm{Pb}$ indicated relatively low contamination of these elements in most of the sampling sites (Fig. $2 \mathrm{~b}$ ).

The $P L I$ values were calculated as a comprehensive pollution index, and these results are also presented in Fig. 2. The PLI values of purplish and yellow soil were in the range of $0.86-1.51$ and $1.03-1.19$, with average values of 1.12 and 1.08 , respectively, and the purple soils were significantly more polluted compared with yellow soils $(F=8.12, p<0.01)$.

PTE concentrations in vegetables. The concentrations (on fresh weight basis, FW) of PTEs in the edible part of vegetable harvested from the study area are presented in Fig. 3. The concentration of Cd in the Chinese cabbage and lettuce leaves were in the range of $0.01-0.24$ and $0.02-0.08 \mathrm{mg} / \mathrm{kg} \mathrm{FW}$, with mean values of 0.04 and $0.04 \mathrm{mg} / \mathrm{kg} \mathrm{FW}$, respectively, which were significantly higher than those in other vegetables $(F=6.51, p<0.001)$. The highest average concentrations of $\mathrm{As}$ and $\mathrm{Pb}$ were in the amaranths and Chinese cabbage $(0.07 \mathrm{and} 0.05 \mathrm{mg} /$ $\mathrm{kg} \mathrm{FW}$, respectively); however, the highest average concentrations of $\mathrm{Cr}$ and $\mathrm{Hg}$ were in the tomatoes and Houttuynia cordatas $(0.07$ and $0.003 \mathrm{mg} / \mathrm{kg} \mathrm{FW}$, respectively). There were few vegetable samples in this study area whose PTEs concentrations exceeded the threshold values ${ }^{43}$.

The PTE concentrations in the four vegetable categories are summarized in Table S2. The average concentration of Cd decreased in the order, leafy $(0.04 \mathrm{mg} / \mathrm{kg} \mathrm{FW})>$ rootstock $(0.01 \mathrm{mg} / \mathrm{kg} \mathrm{FW}) \geq$ legume $(0.01 \mathrm{mg} / \mathrm{kg}$ FW $) \geq$ solanaceous $(0.01 \mathrm{mg} / \mathrm{kg} \mathrm{FW})$; Pb concentration decreased in the order, leafy $(0.04 \mathrm{mg} / \mathrm{kg} \mathrm{FW})>$ rootstock $(0.03 \mathrm{mg} / \mathrm{kg} \mathrm{FW})>$ legume $(0.01 \mathrm{mg} / \mathrm{kg} \mathrm{FW}) \geq$ solanaceous $(0.01 \mathrm{mg} / \mathrm{kg} \mathrm{FW})$; Cr decreased in the order, solanaceous $(0.07 \mathrm{mg} / \mathrm{kg} \mathrm{FW})>$ leafy $(0.03 \mathrm{mg} / \mathrm{kg} \mathrm{FW}) \geq$ legume $(0.03 \mathrm{mg} / \mathrm{kg} \mathrm{FW})>$ rootstock $(0.02 \mathrm{mg} / \mathrm{kg} \mathrm{FW})$; As decreased in the order, leafy $(0.05 \mathrm{mg} / \mathrm{kg} \mathrm{FW})>$ rootstock $(0.03 \mathrm{mg} / \mathrm{kg} \mathrm{FW})>$ legume $(0.01 \mathrm{mg} / \mathrm{kg} \mathrm{FW})>$ solanaceous $(0.003 \mathrm{mg} / \mathrm{kg} \mathrm{FW})$; and $\mathrm{Hg}$ decreased in the order, rootstock $(0.002 \mathrm{mg} / \mathrm{kg} \mathrm{FW})>$ leafy $(0.001 \mathrm{mg} / \mathrm{kg}$ $\mathrm{FW}) \geq$ solanaceous $(0.001 \mathrm{mg} / \mathrm{kg} \mathrm{FW})>$ legume ( less than $0.001 \mathrm{mg} / \mathrm{kg} \mathrm{FW}$ ). These results indicated that leafy 

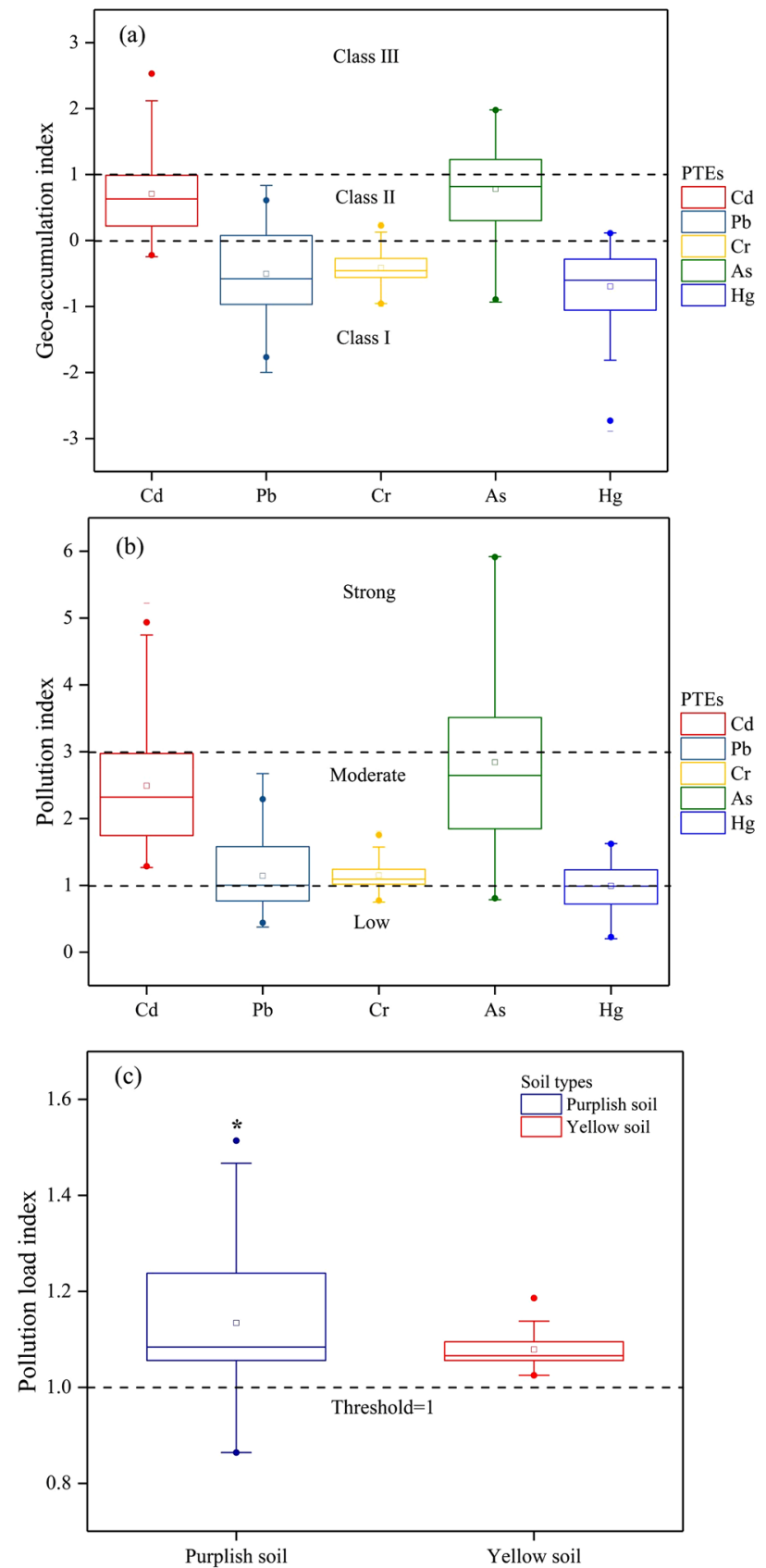

Figure 2. Pollution indices of PTEs in soils; (a) characteristics of geo-accumulation indices of PTEs in soils (Class I = uncontaminated; Class II = uncontaminated to moderately contaminated; Class III = moderately contaminated); (b) characteristics of pollution indices (low, moderate, and strong represent the contamination degrees); (c) characteristics of pollution load indices depending on soil type (small boxes inside the box plots designate the mean values, and $\left(^{*}\right)$ represents the significant differences of the PLI values based on the Duncan test, $p<0.01)$.

and rootstock vegetables were prone to pollution by $\mathrm{Cd}, \mathrm{Pb}$, As and $\mathrm{Hg}$, whereas solanaceous (tomatoes) plants were vulnerable to pollution by $\mathrm{Cr}$.

Non-carcinogenic and carcinogenic risks for local adults and children. The total EDIs of PTEs through a vegetable diet for adults and children in the study area are presented in Table S3. The highest average EDI values for Cd were 0.053 and $0.098 \mathrm{mg} / \mathrm{kg} / \mathrm{day}$ in lettuce leaves for adults and children, respectively. Similarly, the highest $\mathrm{Pb}$ values were 0.061 and $0.115 \mathrm{mg} / \mathrm{kg} /$ day in Chinese cabbage; the highest Cr values were 0.078 and $0.146 \mathrm{mg} / \mathrm{kg} /$ day in tomatoes; the highest As values were 0.081 and $0.151 \mathrm{mg} / \mathrm{kg} /$ day in amaranths; and the highest $\mathrm{Hg}$ values were 0.0034 and $0.0064 \mathrm{mg} / \mathrm{kg} /$ day in Houttuynia cordatas. The aforementioned EDIs of PTEs 

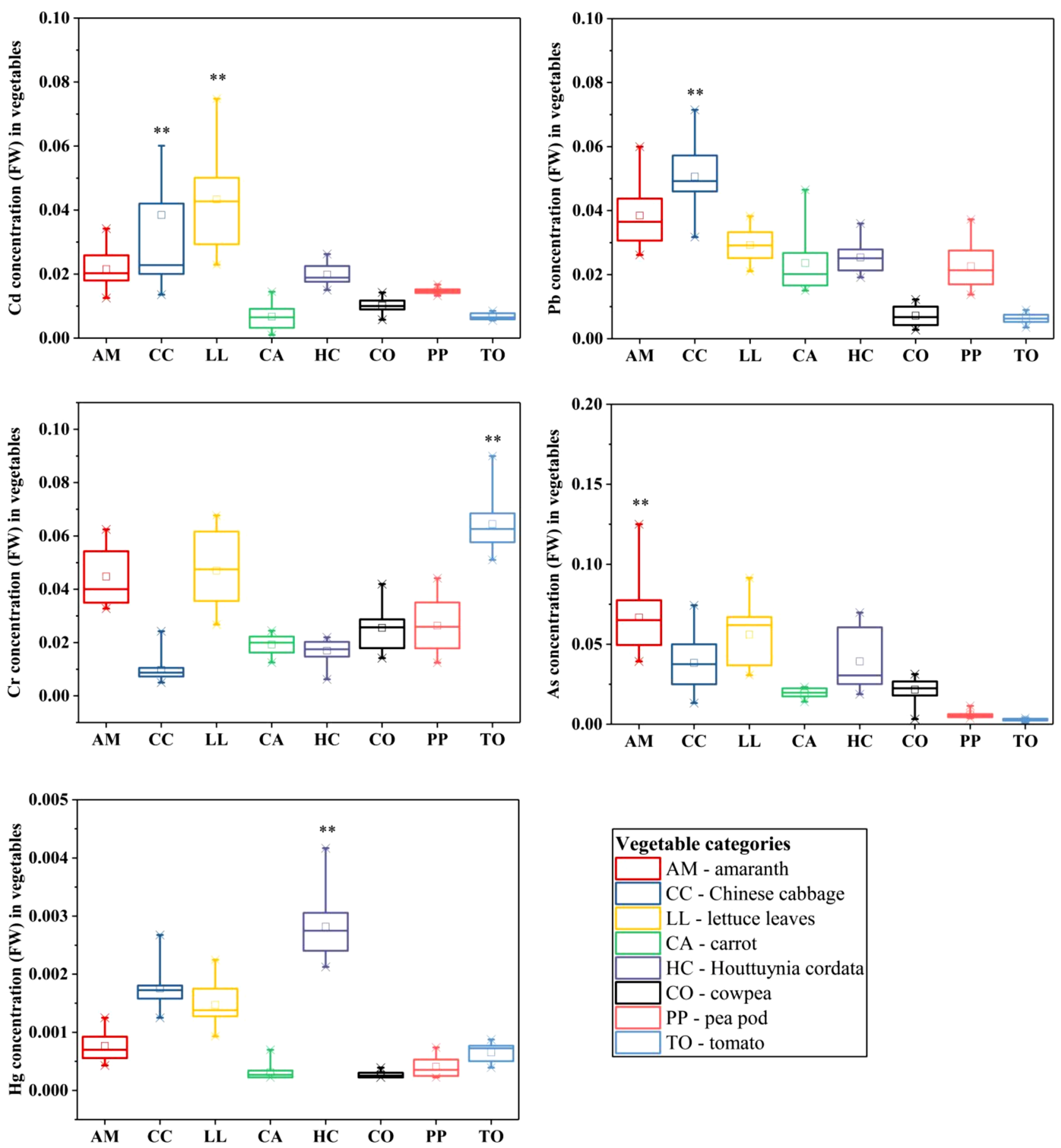

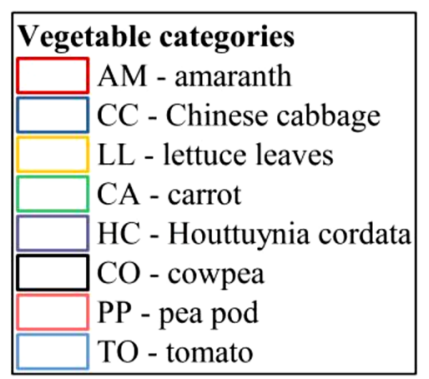

Figure 3. Concentration of PTEs in vegetables (FW) (little box in the middle of the box plots represent the mean values, and $\left.{ }^{* *}\right)$ represent the significant differences of the mean values for PTEs based on the Duncan test, $p<0.01)$.

were significantly different among the studied vegetables, and those determined for children were statistically greater than the values for adults.

The non-carcinogenic risks (HI) of PTEs for local adults and children are described in Fig. 4a,b. For adults, the HI values of lettuce leaves, amaranths, Chinese cabbage, and Houttuynia cordatas $(2.37,2.27,1.82$, and 1.61, respectively) were higher than the threshold value one (Fig. 4a). For children, the HI values of lettuce leaves, amaranths, Chinese cabbage, Houttuynia cordatas, cowpeas and carrots $(4.42,4.23,3.40,2.99,1.50$ and 1.33, respectively) were 1.86 times higher than the analogous values in adults (Fig. 4b). The average contribution of PTEs for adults and children followed the order, As $(54.05 \%)>\mathrm{Cd}(24.39 \%)>\mathrm{Cr}(10.32 \%)>\mathrm{Hg}(6.52 \%)>\mathrm{Pb}$ (4.72\%). Therefore, As poses the highest risks for local adults and children, followed by Cd and Cr. 

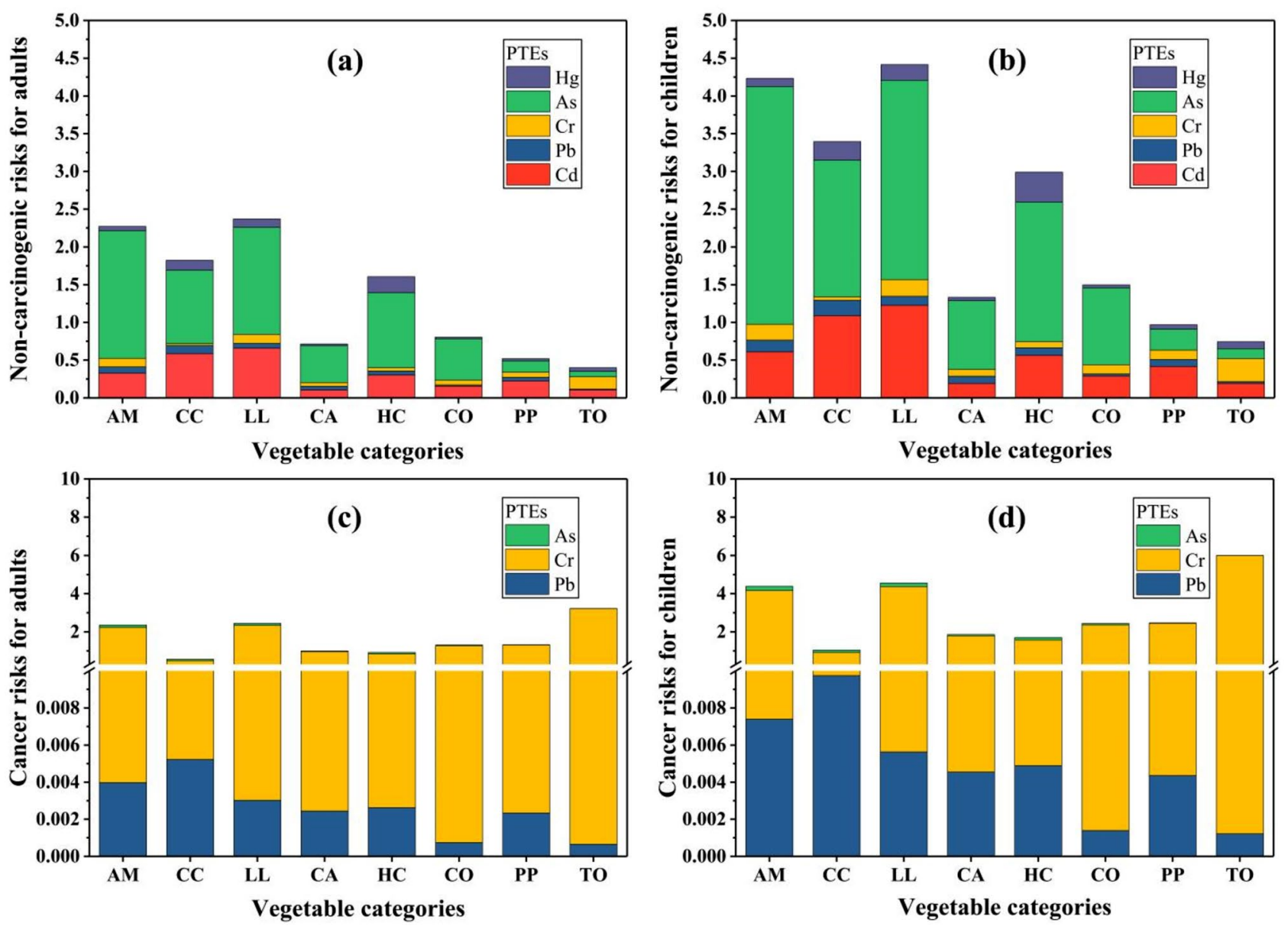

Figure 4. Health risks for adults and children from different vegetables ( $A M$ amaranths, $C C$ Chinese cabbage, $L L$ lettuce leaves, $C A$ carrots, $H C$ Houttuynia cordatas, $C O$ cowpeas, $P P$ pea pods, $T O$ tomatoes).

The cancer risks from PTEs for local people are also shown in Fig. 4c,d. Relative to Cd, the toxic elements $\mathrm{Pb}, \mathrm{Cr}$ and As were associated with higher cancer risks, particularly for $\mathrm{Cr}$ and As. The total combined risk for adults decreased in the following order: tomatoes (3.22) $>$ lettuce leaves $(2.45)>$ amaranths $(2.35)>$ pea pods $(1.32)>$ cowpeas $(1.31)>$ carrots $(1.00)>$ Houttuynia cordatas $(0.92)>$ Chinese cabbage $(0.56)>10^{-4}($ Fig. $4 \mathrm{c})$. The total risk for children decreased in the order: tomatoes $(6.00)>$ lettuce leaves $(4.56)>$ amaranths $(4.39)>$ pea pods (2.47) $>$ cowpeas $(2.44)>$ carrots $(1.86)>$ Houttuynia cordatas $(1.71)>$ Chinese cabbage $(1.05)>10^{-4}$, indicating that children consume vegetables at higher risk than adults (Fig. $4 \mathrm{~d})$.

\section{Discussion}

PTE contamination levels in Chengdu urban vegetable gardens relative to other parts of the world. To compare the PTE concentrations in Chengdu urban vegetable soil with studies conducted in other areas, the PTE concentrations determined in vegetable soils from other regions are compiled in Table 3 . The mean concentrations of $\mathrm{Cd}, \mathrm{Pb}$, and $\mathrm{Hg}$ from Chengdu City were lower than the corresponding mean values from Hangzhou, Wuwei, Xiangyang, Tongling, Ghent, Melbourne, Christchurch, Marseille, Grand Nancy, and Nantes, but higher than the mean values from Marrakech. The city of Marrakech is located in the southwestern region of Morocco, and the area is characterized by soils with high $\mathrm{pH}$ and $\mathrm{SOM}^{44}$. The elevated $\mathrm{pH}$ and/or the formation of metal-organic compounds in the soils there may reduce the mobility of some PTEs, such as Cd and $\mathrm{Pb}^{6,8}$. In contrast, acidic conditions tend to promote the movement of toxic metals as a result of proton competition and decreased availability of negatively-charged binding sites ${ }^{45}$. In addition, such conditions increase ionic metal speciation because of the weak binding effect of SOM on soil components, which may further enhance the mobility and bioavailability of metals ${ }^{46}$. This could be a reason for the high $\mathrm{Cd}, \mathrm{Pb}$, and $\mathrm{Hg}$ levels detected in the soil from Hangzhou, Wuwei, Xiangyang, Tongling, Ghent, Marseille, Grand Nancy, and Nantes. Meanwhile, the average concentrations of $\mathrm{Cr}$ and As in soils from Chengdu City were consistently greater than the values in all other studies, and the concentrations varied highly among the different locations (Table 3 ). This indicates that some of the PTEs in urban vegetable soils have higher spatial variability due to the different soil types, soil properties, climates, levels of development, and human activities in the different regions $\mathrm{s}^{5,47-49}$.

Although the origin of PTEs in soils may be either lithogenic or anthropogenic, in most cases, high PTE concentrations are associated with human-induced activities ${ }^{50,51}$. The results from $I_{\text {geo }}$ and $P I$ calculations both 


\begin{tabular}{|c|c|c|c|c|c|c|c|c|c|}
\hline \multirow[b]{2}{*}{ Study area } & \multirow[b]{2}{*}{ Sample number } & \multicolumn{5}{|c|}{ Concentration (range, mean, mg/kg) } & \multicolumn{2}{|c|}{ Soil property (range, mean) } & \multirow[b]{2}{*}{ Reference } \\
\hline & & Cd & \begin{tabular}{|l|l|}
$\mathbf{P b}$ & \\
\end{tabular} & $\mathrm{Cr}$ & As & $\mathrm{Hg}$ & pH & SOM (g/kg) & \\
\hline $\begin{array}{l}\text { Chengdu } \\
\text { (China) }\end{array}$ & 113 & $0.10-0.69(0.22)$ & \begin{tabular}{|l|}
$11.59-82.60$ \\
$(35.29)$
\end{tabular} & \begin{tabular}{|l|}
$59.21-143.14$ \\
$(90.91)$
\end{tabular} & $\begin{array}{l}8.17-61.57 \\
(29.57)\end{array}$ & $0.01-0.10(0.06)$ & $4.3-8.0(6.6)$ & $\begin{array}{l}10.3-153.9 \\
(55.6)\end{array}$ & This study \\
\hline $\begin{array}{l}\text { Hangzhou } \\
\text { (China) }\end{array}$ & 268 & $0.16-2.14(0.72)$ & \begin{tabular}{|l|}
$1.52-191.27$ \\
$(68.64)$
\end{tabular} & \begin{tabular}{|l|}
$26.78-68.99$ \\
$(47.74)$
\end{tabular} & $\begin{array}{l}5.22-52.14 \\
(15.51)\end{array}$ & $0.12-1.45(0.76)$ & $4.5-8.4(6.4)$ & $6.9-59.7(23.9)$ & Liu et al., 2013 \\
\hline Wuwei (China) & 97 & $0.10-1.53(0.42)$ & \begin{tabular}{|l|}
$15.33-27.89$ \\
$(20.76)$
\end{tabular} & $\begin{array}{l}40.08-60.48 \\
(53.12)\end{array}$ & & & $7.4-8.3(7.9)$ & $10.4-52.3(29.7)$ & Bai et al., 2014 \\
\hline $\begin{array}{l}\text { Xiangyang } \\
\text { (China) }\end{array}$ & 136 & & $\begin{array}{l}24.25-132.55 \\
(39.44)\end{array}$ & \begin{tabular}{|l|}
$31.3-70.3$ \\
$(55.36)$
\end{tabular} & \begin{tabular}{|l|}
$3.48-11.89$ \\
$(8.35)$
\end{tabular} & $0.01-0.54(0.13)$ & $7.0-8.3(7.6)$ & $35.3-80.0(47.6)$ & $\begin{array}{l}\text { Wang et al., } \\
2017\end{array}$ \\
\hline $\begin{array}{l}\text { Tongling } \\
\text { (China) }\end{array}$ & 44 & $0.2-3.6(1.2)$ & $19-198(66)$ & & & & $5.7-7.9(7.1)$ & $13.3-90.5(25.2)$ & Xu et al., 2013 \\
\hline Ghent (Belgium) & 26 & $0.16-4.91(0.53)$ & \begin{tabular}{|l|}
$14.86-303.3$ \\
$(97.5)$
\end{tabular} & $\begin{array}{l}8.69-143.6 \\
(26.4)\end{array}$ & $1.97-8.52(4.39)$ & & $(5.9)$ & $36-264$ & \begin{tabular}{|l} 
Folens et al., \\
2017
\end{tabular} \\
\hline $\begin{array}{l}\text { Melbourne } \\
\text { (Australia) }\end{array}$ & 108 & $0.1-1.0(0.5)$ & $\begin{array}{l}12.9-723.0 \\
(102.2)\end{array}$ & $11.6-49.4(26)$ & & & $5.9-7.5(6.9)$ & $92-637(231)$ & $\begin{array}{l}\text { Kandic et al., } \\
2019\end{array}$ \\
\hline $\begin{array}{l}\text { Christchurch } \\
\text { (New Zealand) }\end{array}$ & 50 & $0.33-10.7(1.20)$ & $22.6-2615(137)$ & $14.1-133(22.7)$ & $4.34-72.2(12.1)$ & $0.03-308(0.29)$ & & & $\begin{array}{l}\text { Ashrafzadeh } \\
\text { et al., } 2017\end{array}$ \\
\hline $\begin{array}{l}\text { Marseille, Grand } \\
\text { Nancy and } \\
\text { Nantes (France) }\end{array}$ & 104 & $0.1-8.9(0.5)$ & $19.5-566(98.6)$ & $21.3-136(55.3)$ & $0.2-65.2(21.1)$ & & $6.2-8.3(7.6)$ & $17-103(49)$ & $\begin{array}{l}\text { Joimel et al., } \\
2020\end{array}$ \\
\hline $\begin{array}{l}\text { Marrakech } \\
\text { (Morocco) }\end{array}$ & 11 & $0.07-0.36(0.20)$ & \begin{tabular}{|l|}
$8.12-58.68$ \\
$(23.12)$
\end{tabular} & \begin{tabular}{|l|}
$23.6-86.09$ \\
$(42.83)$
\end{tabular} & $\begin{array}{l}5.13-11.87 \\
(7.71)\end{array}$ & & $7.0-8.5(7.9)$ & $138-271(220.5)$ & $\begin{array}{l}\text { Laaouidi et al., } \\
2020\end{array}$ \\
\hline \multicolumn{10}{|l|}{ Regulation values } \\
\hline China & & 0.3 & 90 & 150 & 40 & 1.8 & $5.5-6.5$ & & CEPA (2018) \\
\hline EC & & 1.5 & 100 & 100 & & & & & EC (2000) \\
\hline WHO/FAO & & $3-6$ & $250-500$ & 100 & 20 & & & & $\begin{array}{l}\text { WHO/FAO } \\
(2007)\end{array}$ \\
\hline
\end{tabular}

Table 3. Descriptive statistics of PTEs in urban and/or suburban garden vegetable soils (values in brackets are the mean values).

indicated that the soils of Chengdu City were lesser enriched with Cr relative to the other elements (Fig. 2), suggesting that $\mathrm{Cr}$ in this study area originate from a natural source; this conclusion was consistent with a published result ${ }^{22}$. However, the results of Spearman correlation analysis, PCA, and CA indicated that Cd, Pb, and Hg exclusively (and As partially) had a common source, which may imply anthropogenic inputs, which would be consistent with previous reports ${ }^{27,52}$. In the present study, Cd and As clearly contributed the most to soil contamination in the investigated area compared with the other elements (Fig. 2). These results were similar to previous studies, which were conducted on urban vegetable garden soil of other regions. For example, the mean level of $\mathrm{Cd}$ in garden vegetable soils from Xiangyang City in northeast China was 2.13 times higher than the background value ${ }^{52}$. Moreover, the Cd concentration in urban garden soils in China was reported to be higher than the concentrations of other PTEs ${ }^{53}$. Antoniadis et al. found that the As concentration in garden vegetable soils in Cologne was 5.0-86.2 times higher than the background value $\mathrm{e}^{54}$. It was generally acknowledged that there are many factors that contribute to $\mathrm{Cd}$ and As accumulation in urban vegetable soils, including irrigation with domestic and industrial wastewater, aerial deposition of industrial dust plums and automobile exhaust, application of pesticides and fertilizers to the soil, and other garden practices ${ }^{54}$. Typically, Cd is considered as a toxic element marker of agronomic practices, including the use of chemical fertilizers and livestock, which represent key sources of Cd introduction into soil ${ }^{55}$. According to a previous report ${ }^{56}$, inorganic As compounds, such as sodium arsenate, calcium arsenate, and many others were widely applied as herbicides and pesticides, thereby becoming important sources of As in urban vegetable soils.

PTE contamination in vegetables. The varied in metal concentrations among the studied vegetables implied that the vegetable species had unique abilities and capacities to take up and accumulate the PTEs. The mean $\mathrm{Cd}, \mathrm{Pb}$, and As concentrations in leafy vegetables were higher than those in other vegetable categories. Among the leafy vegetables, the Cd concentrations in the Chinese cabbage and lettuce leaves were significantly higher than in other vegetables, and the $\mathrm{Pb}$ and $\mathrm{As}$ concentrations in Chinese cabbage and amaranths were the highest, with mean values of 0.051 and $0.067 \mathrm{mg} / \mathrm{kg} \mathrm{FW}$, respectively. Chaturvedi et al. reported that spinach plants (a leafy vegetable) could accumulate high amounts of $\mathrm{Cd}, \mathrm{Pb}$, and $\mathrm{As}$ in the edible parts, and no visible signs of toxicity were observed, which was consistent with the BAF results of the present study (Table S2) ${ }^{37}$.

The highest level of $\mathrm{Hg}$ in vegetables was found in rootstocks, particularly in the Houttuynia cordatas. This was consistent with a report from Wang et al. who detected higher Hg concentrations in Houttuynia cordatas compared to five other vegetables, and the highest $\mathrm{Hg}$ concentration was 14.5 times greater than the permissible level $(0.01 \mathrm{mg} / \mathrm{kg} \mathrm{FW})^{35}$. Several studies have reported Hg concentrations in rootstock vegetables, along with some potential accumulation mechanisms. Carrasco-Gil et al. found that phytochelatins contributed to the retention of $\mathrm{Hg}$ in the roots owing to their ability to sequester $\mathrm{Hg}$ and facilitate $\mathrm{Hg}$ transport from cytosol to vacuole, thereby immobilizing $\mathrm{Hg}$ in the roots ${ }^{37}$. However, uptake of $\mathrm{Hg}$ is species-dependent ${ }^{57}$. Indeed, the concentration 


\begin{tabular}{|l|l|l|l|l|l|l|l|}
\hline & $\mathbf{p H}$ & $\mathbf{S O M}$ & $\mathbf{S}(\mathbf{C d})$ & $\mathbf{S}(\mathbf{P b})$ & $\mathbf{S}(\mathbf{C r})$ & $\mathbf{S}(\mathbf{A s})$ & $\mathbf{S}(\mathbf{H g})$ \\
\hline $\mathrm{V}(\mathrm{Cd})$ & $-0.710^{* *}$ & $-0.342^{* *}$ & -0.057 & -0.028 & 0.146 & $0.362^{* *}$ & -0.120 \\
\hline $\mathrm{V}(\mathrm{Pb})$ & $-0.423^{* *}$ & $-0.414^{* *}$ & 0.090 & 0.019 & $0.260^{* *}$ & $0.420^{* *}$ & $-0.219^{*}$ \\
\hline $\mathrm{V}(\mathrm{Cr})$ & 0.147 & 0.045 & $-0.191^{*}$ & 0.015 & $-0.398^{* *}$ & -0.063 & -0.044 \\
\hline $\mathrm{V}(\mathrm{As})$ & $-0.402^{* *}$ & $-0.371^{* *}$ & -0.045 & -0.039 & 0.017 & $0.387^{* *}$ & -0.130 \\
\hline $\mathrm{V}(\mathrm{Hg})$ & $-0.441^{* *}$ & -0.153 & -0.124 & -0.034 & 0.046 & $0.348^{* *}$ & -0.073 \\
\hline
\end{tabular}

Table 4. Spearman correlation matrix for soil characteristics and PTEs in vegetables $(n=113)$. ${ }^{\star}$ Significant

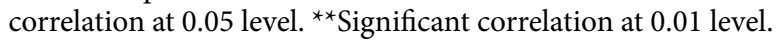

of $\mathrm{Hg}$ in Houttuynia cordatas was 9.02 times higher than that in carrots despite the fact that these were both categorized as rootstock vegetables. The $\mathrm{Cr}$ concentration in tomatoes was higher than in all other vegetables.

The relationships between the PTE concentrations in vegetables and their growing soil characteristics are presented in Table 4. A significant positive correlation for As $(r=0.387, p<0.01)$ was observed, indicating that the soil As concentration could likely somewhat predict the amount of As in the edible parts of the vegetables. Negative correlations were observed for $\mathrm{Cr}, \mathrm{Cd}$, and $\mathrm{Hg}$, indicating that the soil-to-plant transfer factors decreased with increasing concentrations of these elements in vegetables ${ }^{58}$, especially $\mathrm{Cr}(r=-0.398, p<0.01)$. However, the total PTE concentration in soil may not be the only crucial factor controlling the metal bioavailability and vegetable uptake; these aspects also depend on other geochemical variables ${ }^{59}$. It is important to note from Table 4 that significant negative correlations were found between $\mathrm{pH}$ and $\mathrm{Cd}, \mathrm{Pb}$, As, and $\mathrm{Hg}$, while $\mathrm{SOM}$ was negatively correlated with $\mathrm{Cd}, \mathrm{Pb}$, and As. Kirkham et al. and Tsadilas et al. pointed out that the Cd content in plants decreased as the soil $\mathrm{pH}$ increased ${ }^{60,61}$. Additionally, the uptake of $\mathrm{Pb}$ by the three vegetable types increased in acidic soil environments ${ }^{62}$.

Health risks for local people. Evaluating the human risk associated with contaminated vegetable consumption also requires relating the problems of PTE pollution with the vegetable consumption trends. The EDIs of the studied metals were determined according to the mean concentration of each metal in each vegetable species, and considering the respective consumption rate for each species ${ }^{63}$. Some recent reports have confirmed that contaminated vegetables may be significant contributors to the total dietary PTE intake, particularly in terms of $\mathrm{Cd}, \mathrm{As}$, and $\mathrm{Pb}^{25,55,64}$. In the present study, it may seem comforting that the PTEs concentrations in vegetables were often below the maximum permissible limits. Nevertheless, there was a significant increase in health risks associated with exposure to these toxic elements, especially for $\mathrm{Cr}$ and As (Fig. 4). This may be attributed to the relatively high EDIs of $\mathrm{Cr}$ and As (Table S3). The total intake of $\mathrm{Cd}, \mathrm{Pb}, \mathrm{Cr}, \mathrm{As}$ and $\mathrm{Hg}$ via vegetables consumption were found to be $0.20,0.25,0.31,0.30$ and $0.01 \mathrm{mg} / \mathrm{kg} /$ day for adult whereas $0.37,0.46,0.58,0.57$ and $0.02 \mathrm{mg} / \mathrm{kg} /$ day for children, respectively (Table S3). The total EDIs of Cd, Pb, Cr and As were 4.75, 1.14, 1.5 and 2.5 times higher than the maximum tolerable daily intake (MTDI) for adult whereas 7.82, 2.19, 2.85 and 4.66 times higher for children indicated that these metals could pose potential health risk via vegetables consumption in the study area.

The hazard index results suggested an overall non-carcinogenic health effect of the toxic elements on human. It is important to note that HI values for lettuce leaves, amaranths, Chinese cabbage and Houttuynia cordatas surpassed the threshold level $(\mathrm{HI}>1)$ for adults and children (Fig. 4a,b). Several other reports found HI values greater than one due to vegetable consumption ${ }^{18,19,64}$. In terms of individual metals, As contributed significantly to the non-carcinogenic health hazard, followed by $\mathrm{Cd}$ and $\mathrm{Cr}$. The results highlighted that people in the study area could encounter severe non-carcinogenic health risks following consumption of the studied vegetables.

The calculated carcinogenic health risk associated with $\mathrm{Cr}$ and As ingestion from consuming the studied vegetables indicated that tomatoes, lettuce leaves and amaranths induced serious cancer risks exceeding the threshold value in adults and children (Fig. 4c,d). In terms of individual metals, Cr exhibited a higher cancer risk than As. The total carcinogenic risk of the studied vegetables was higher than the USEPA standard $\left(10^{-4}\right)$, thus confirming the cancer risk to adults and children in the study area ${ }^{65,66}$. Several study was reported similar cancer risk values based on vegetable consumption ${ }^{18,19,64}$. However, it is difficult to understand the true potential human health risks based on total PTE concentrations without considering the bioaccessible forms of the metals ${ }^{18}$. Alarmingly, the present study revealed that consumption of contaminated urban garden vegetables would definitely pose carcinogenic health risks on its consumers through the combined effects of the toxic elements present after being taken up from the soil.

\section{Conclusions}

Urban vegetable gardening is common, but exposure to PTEs originating from industrial activities or irrigation with polluted water tainted by domestic sewage or heavy traffic requires urgent attention. The mean concentration of metals in soil was reported in the decreasing order of $\mathrm{Cr}>\mathrm{Pb}>\mathrm{As}>\mathrm{Cd}>\mathrm{Hg}$. Most of samples exceeded the background values for PTEs. Vegetables were also contaminated with metals. Higher Cd concentration was found in lettuce leaves $(0.04 \mathrm{mg} / \mathrm{kg} \mathrm{FW})$ and $\mathrm{Pb}$ in Chinese cabbage $(0.05 \mathrm{mg} / \mathrm{kg} \mathrm{FW})$, Cr in tomatoes $(0.07 \mathrm{mg} /$ $\mathrm{kg} \mathrm{FW})$, As in amaranths $(0.07 \mathrm{mg} / \mathrm{kg} \mathrm{FW})$, respectively. The pollution load index values indicated that the soils in urban gardens were polluted with PTEs, often beyond the threshold limits. Estimated daily intake of metals due to vegetables consumption reveled that total EDIs of $\mathrm{Cd}, \mathrm{Pb}, \mathrm{Cr}$ and As were 4.75, 1.14, 1.5 and 2.5 times 
higher than the maximum tolerable daily intake (MTDI) for adult whereas 7.82, 2.19, 2.85 and 4.66 times higher for children. The health risk assessment also confirmed that exposure to $\mathrm{Cd}$ and As presented the greatest noncarcinogenic risk (>1), while Cr exposure was associated with the highest cancer risk (>E04). Furthermore, the risk of exposure was even higher for children compared with adults. Therefore, the results of this study indicate that more regulative and preventative measures should be adopted by community health care services to combat further accumulation of these metals in the urban vegetable gardens of southwest China.

\section{Data availability}

The datasets used and/or analyzed during the current study are available from the corresponding author on reasonable request.

Received: 8 April 2021; Accepted: 9 November 2021

Published online: 24 November 2021

\section{References}

1. Lu, Y., Zhu, F., Chen, J., Gan, H. \& Guo, Y. Chemical fractionation of heavy metals in urban soils of Guangzhou, China. Environ. Monit. Assess. 134, 429-439 (2007).

2. Kormoker, T. et al. Toxic metals in agricultural soils near the industrial areas of Bangladesh: Ecological and human health risk assessment. Toxin Rev. 19, 1-20 (2019).

3. Wang, L., Tao, W., Smardon, R. C., Xu, X. \& Lu, X. Speciation, sources, and risk assessment of heavy metals in suburban vegetable garden soil in Xianyang City, Northwest China. Front. Earth Sci. 12, 397-407 (2018).

4. He, B., Yun, Z., Shi, J. \& Jiang, G. Research progress of heavy metal pollution in China: Sources, analytical methods, status, and toxicity. Chinese Sci. Bull. 58, 134-140 (2013).

5. Pan, L., Ma, J., Wang, X. \& Hou, H. Heavy metals in soils from a typical county in Shanxi Province, China: Levels, sources and spatial distribution. Chemosphere 148, 248-254 (2016).

6. Cai, L.-M. et al. Heavy metal contamination and health risk assessment for children near a large Cu-smelter in central China. Sci. Total Environ. 650, 725-733 (2019).

7. Cai, L. et al. Source identification of eight hazardous heavy metals in agricultural soils of Huizhou, Guangdong Province, China. Ecotoxicol. Environ. Saf. 78, 2-8 (2012).

8. Cai, L.-M., Wang, Q.-S., Wen, H.-H., Luo, J. \& Wang, S. Heavy metals in agricultural soils from a typical township in Guangdong Province, China: Occurrences and spatial distribution. Ecotoxicol. Environ. Saf. 168, 184-191 (2019).

9. Zhang, X. et al. Impacts of lead/zinc mining and smelting on the environment and human health in China. Environ. Monit. Assess. 184, 2261-2273 (2012)

10. Pan, H., Lu, X. \& Lei, K. A comprehensive analysis of heavy metals in urban road dust of Xian, China: Contamination, source apportionment and spatial distribution. Sci. Total Environ. 609, 1361-1369 (2017).

11. Men, C. et al. Pollution characteristics, risk assessment, and source apportionment of heavy metals in road dust in Beijing, China. Sci. Total Environ. 612, 138-147 (2018).

12. Proshad, R., Zhang, D., Uddin, M. \& Wu, Y. Presence of cadmium and lead in tobacco and soil with ecological and human health risks in Sichuan province, China. Environ. Sci. Pollut. Res. 20, 1-16 (2020).

13. Huang, Z., Pan, X.-D., Wu, P.-G., Han, J.-L. \& Chen, Q. Heavy metals in vegetables and the health risk to population in Zhejiang, China. Food Control 36, 248-252 (2014).

14. Crispo, M. et al. Heavy metals and metalloids concentrations across UK urban horticultural soils and the factors influencing their bioavailability to food crops. Environ. Pollut. 288, 117960 (2021).

15. Tobarra, M. A., López, L. A., Cadarso, M. A., Gómez, N. \& Cazcarro, I. Is seasonal households' consumption good for the nexus carbon/water footprint? The Spanish fruits and vegetables case. Environ. Sci. Technol. 52, 12066-12077 (2018).

16. Huang, Y. et al. Heavy metal pollution and health risk assessment of agricultural soils in a typical peri-urban area in southeast China. J. Environ. Manag. 207, 159-168 (2018).

17. Proshad, R., Kormoker, T., Islam, M. S. \& Chandra, K. Potential health risk of heavy metals via consumption of rice and vegetables grown in the industrial areas of Bangladesh. Hum. Ecol. Risk Assess. Int. J. 19, 1-23 (2019).

18. Kormoker, T. et al. Concentrations, source apportionment and potential health risk of toxic metals in foodstuffs of Bangladesh. Toxin Rev. 41, 1-14 (2020).

19. Islam, M. S. et al. Assessment of heavy metals in foods around the industrial areas: Health hazard inference in Bangladesh. Geocarto Int. 35, 280-295 (2020).

20. Sayeed, A. et al. Nutritional status of exotic and indigenous vegetables. Int. J. Veg. Sci. https://doi.org/10.1080/19315260.2020. 1713957 (2020).

21. Xu, X., Zhao, Y., Zhao, X., Wang, Y. \& Deng, W. Sources of heavy metal pollution in agricultural soils of a rapidly industrializing area in the Yangtze Delta of China. Ecotoxicol. Environ. Saf. 108, 161-167 (2014).

22. Ye, X. et al. Assessment of heavy metal pollution in vegetables and relationships with soil heavy metal distribution in Zhejiang province, China. Environ. Monit. Assess. 187, 1-9 (2015).

23. Xu, C. U. I. et al. Concentrations of heavy metals in suburban horticultural soils and their uptake by Artemisia selengensis. Pedosphere 25, 878-887 (2015).

24. Tian, K. et al. Determination and evaluation of heavy metals in soils under two different greenhouse vegetable production systems in eastern China. Chemosphere 165, 555-563 (2016).

25. Cai, L. et al. Multivariate and geostatistical analyses of the spatial distribution and source of arsenic and heavy metals in the agricultural soils in Shunde, Southeast China. J. Geochem. Explor. 148, 189-195 (2015).

26. Tao, J. et al. Chemical composition of PM 2.5 at an urban site of Chengdu in southwestern China. Adv. Atmos. Sci. 30, 1070-1084 (2013).

27. Chen, T. et al. Identification of trace element sources and associated risk assessment in vegetable soils of the urban-rural transitional area of Hangzhou, China. Environ. Pollut. 151, 67-78 (2008).

28. China, A. C. C. of Conventional Methods of Soil and Agricultural Chemistry Analysis. (1983).

29. Bermejo, J. C. S., Beltrán, R. \& Ariza, J. L. G. Spatial variations of heavy metals contamination in sediments from Odiel river (Southwest Spain). Environ. Int. 29, 69-77 (2003).

30. Nikolaidis, C., Zafiriadis, I., Mathioudakis, V. \& Constantinidis, T. Heavy metal pollution associated with an abandoned lead-zinc mine in the Kirki Region, NE Greece. Bull. Environ. Contam. Toxicol. 85, 307-312 (2010).

31. Li, Z., Ma, Z., van der Kuijp, T. J., Yuan, Z. \& Huang, L. A review of soil heavy metal pollution from mines in China: Pollution and health risk assessment. Sci. Total Environ. 468, 843-853 (2014).

32. Lee, C. S., Li, X., Shi, W., Cheung, S. C. \& Thornton, I. Metal contamination in urban, suburban, and country park soils of Hong Kong: A study based on GIS and multivariate statistics. Sci. Total Environ. 356, 45-61 (2006). 
33. Guo, G., Wu, F., Xie, F. \& Zhang, R. Spatial distribution and pollution assessment of heavy metals in urban soils from southwest China. J. Environ. Sci. 24, 410-418 (2012).

34. Khan, S., Cao, Q., Zheng, Y. M., Huang, Y. Z. \& Zhu, Y. G. Health risks of heavy metals in contaminated soils and food crops irrigated with wastewater in Beijing, China. Environ. Pollut. 152, 686-692 (2008).

35. Wang, Q. et al. Vegetable Houttuynia cordata Thunb. as an important human mercury exposure route in Kaiyang county, Guizhou province, SW China. Ecotoxicol. Environ. Saf. 197, 110575 (2020).

36. USEPA. Exposure Factors Handbook. (National Center for Environmental Assessment Office of Research and Development (EPA/600/R-09/052 F), 2011).

37. Chaturvedi, R., Favas, P. J. C., Pratas, J., Varun, M. \& Paul, M. S. Metal (loid) induced toxicity and defense mechanisms in Spinacia oleracea L.: Ecological hazard and prospects for phytoremediation. Ecotoxicol. Environ. Saf. 183, 109570 (2019).

38. USEPA. Supplemental Guidance for Developing Soil Screening Levels for Superfund Sites. (Office of Solid Waste and Emergency Response (OSWER9355.4-24), 2002).

39. USDOE. The Risk Assessment Information System. (Department of Energy's Oak Ridge Operations Office, 2011).

40. CNEMC. The Background Values of Chinese Soils. 67-85. (Environmental Science Press of China, 1990).

41. Micó, C., Recatalá, L., Peris, M. \& Sánchez, J. Assessing heavy metal sources in agricultural soils of an European Mediterranean area by multivariate analysis. Chemosphere 65, 863-872 (2006).

42. Shaheen, S. M. et al. Potentially toxic elements in saltmarsh sediments and common reed (Phragmites australis) of Burullus coastal lagoon at North Nile Delta, Egypt: A survey and risk assessment. Sci. Total Environ. 649, 1237-1249 (2019).

43. NHFPC and CFDA. National Standard for Food Safety: Limits of Pollutants in Food. GB2762-2017. (NHFPC and CFDA, 2017) (in Chinese).

44. Laaouidi, Y. et al. Trace elements in soils and vegetables from market gardens of urban areas in Marrakech City. Biol. Trace Elem. Res. 19, 1-16 (2019).

45. Horckmans, L., Swennen, R. \& Deckers, J. Retention and release of $\mathrm{Zn}$ and $\mathrm{Cd}$ in spodic horizons as determined by pH stat analysis and single extractions. Sci. Total Environ. 376, 86-99 (2007).

46. Naidu, R., Oliver, D. \& McConnell, S. Heavy metal phytotoxicity in soils. in Proceeding of the 5th National Workshop on the Assessment of Site Contamination (eds. Langley, A., Gilbey, M., Kennedy, B.). 235-241 (2003).

47. Zhang, J., Wang, Y., Liu, J., Liu, Q. \& Zhou, Q. Multivariate and geostatistical analyses of the sources and spatial distribution of heavy metals in agricultural soil in Gongzhuling, Northeast China. J. Soils Sedim. 16, 634-644 (2016).

48. Shao, D., Zhan, Y., Zhou, W. \& Zhu, L. Current status and temporal trend of heavy metals in farmland soil of the Yangtze River Delta Region: Field survey and meta-analysis. Environ. Pollut. 219, 329-336 (2016).

49. Wei, L., Liu, G. \& Wu, D. Characteristics and provenance of hazardous trace elements in soil from a typical agricultural region in eastern Anhui. China. Geosci. J. 24, 1-10 (2020).

50. Salmon, S. U. et al. Reactive transport controls on sandy acid sulfate soils and impacts on shallow groundwater quality. Water Resour. Res. 50, 4924-4952 (2014).

51. Hooda, P. Trace Elements in Soils. (Wiley, 2010).

52. Wang, Z. et al. Spatial distribution and sources of heavy metals in natural pasture soil around copper-molybdenum mine in Northeast China. Ecotoxicol. Environ. Saf. 154, 329-336 (2018).

53. Wei, B. \& Yang, L. A review of heavy metal contaminations in urban soils, urban road dusts and agricultural soils from China. Microchem. J. 94, 99-107 (2010).

54. Antoniadis, V. et al. Trace elements in the soil-plant interface: Phytoavailability, translocation, and phytoremediation-A review. Earth-Sci. Rev. 171, 621-645 (2017).

55. Sun, C., Liu, J., Wang, Y., Sun, L. \& Yu, H. Multivariate and geostatistical analyses of the spatial distribution and sources of heavy metals in agricultural soil in Dehui, Northeast China. Chemosphere 92, 517-523 (2013).

56. Hu, W. et al. Source identification of heavy metals in peri-urban agricultural soils of southeast China: An integrated approach. Environ. Pollut. 237, 650-661 (2018).

57. Liu, W., Zhou, Q., Sun, Y. \& Liu, R. Identification of Chinese cabbage genotypes with low cadmium accumulation for food safety. Environ. Pollut. 157, 1961-1967 (2009).

58. Wang, G. et al. Transfer characteristics of cadmium and lead from soil to the edible parts of six vegetable species in southeastern China. Environ. Pollut. 144, 127-135 (2006).

59. Augustsson, A. et al. Challenges in assessing the health risks of consuming vegetables in metal-contaminated environments. Environ. Int. 113, 269-280 (2018).

60. Tsadilas, C. D., Karaivazoglou, N. A., Tsotsolis, N. C., Stamatiadis, S. \& Samaras, V. Cadmium uptake by tobacco as affected by liming, N form, and year of cultivation. Environ. Pollut. 134, 239-246 (2005).

61. Kirkham, M. B. Cadmium in plants on polluted soils: Effects of soil factors, hyperaccumulation, and amendments. Geoderma 137, 19-32 (2006).

62. Rahman, M. M., Azirun, S. M. \& Boyce, A. N. Enhanced accumulation of copper and lead in amaranth (Amaranthus paniculatus), Indian mustard (Brassica juncea) and sunflower (Helianthus annuus). PLoS ONE 8, e62941 (2013).

63. Santos, E. E., Lauria, D. C. \& Da Silveira, C. L. P. Assessment of daily intake of trace elements due to consumption of foodstuffs by adult inhabitants of Rio de Janeiro city. Sci. Total Environ. 327, 69-79 (2004).

64. Proshad, R., Kormoker, T. \& Islam, S. Distribution, source identification, ecological and health risks of heavy metals in surface sediments of the Rupsa River, Bangladesh. Toxin Rev. 1-25 (2019).

65. USEPA. Risk Based Concentration Table. http://www.epa.gov/reg3hwmd/risk/human/index.htm. (2010).

66. USEPA. Risk Based Screening Table. Composite Table: Summary Tab 0615. http://www2.epa.gov/risk/riskbasedscreeningtablege nerictables. (2015).

\section{Acknowledgements}

This work was financially supported by the Project of Institute of Atmospheric Physics, Chinese Academy of Sciences, China. We would like to express our gratitude towards garden owners who were open to us while collecting vegetables.

\section{Author contributions}

J.G. conceived and designed the experiments, and wrote the main manuscript text. D.Z. revised this manuscript critically for important content. R.P. analyzed the data. E.U. performed the experiments. Z.W. thoroughly revised and improved the manuscript.

\section{Funding}

This work was supported by the Project of Institute of Atmospheric Physics, Chinese Academy of Sciences, China. 


\section{Competing interests}

The authors declare no competing interests.

\section{Additional information}

Supplementary Information The online version contains supplementary material available at https://doi.org/ 10.1038/s41598-021-02069-6.

Correspondence and requests for materials should be addressed to D.Z.

Reprints and permissions information is available at www.nature.com/reprints.

Publisher's note Springer Nature remains neutral with regard to jurisdictional claims in published maps and institutional affiliations.

(c) (1) Open Access This article is licensed under a Creative Commons Attribution 4.0 International License, which permits use, sharing, adaptation, distribution and reproduction in any medium or format, as long as you give appropriate credit to the original author(s) and the source, provide a link to the Creative Commons licence, and indicate if changes were made. The images or other third party material in this article are included in the article's Creative Commons licence, unless indicated otherwise in a credit line to the material. If material is not included in the article's Creative Commons licence and your intended use is not permitted by statutory regulation or exceeds the permitted use, you will need to obtain permission directly from the copyright holder. To view a copy of this licence, visit http://creativecommons.org/licenses/by/4.0/.

(C) The Author(s) 2021 